EduHumaniora: Jurnal Pendidikan Dasar | p-ISSN 2085-1243

Vol. 8. No.1 Januari 2016 | Hal 1-11

\title{
DESAIN DIDAKTIS SOAL CERITA OPERASI HITUNG CAMPURAN UNTUK KELAS III SEKOLAH DASAR
}

Oleh:

Sahid Agus Nurhamid ${ }^{1}$, Didi Suryadi ${ }^{2}$

Universitas Pendidikan Indonesia

\begin{abstract}
This research based on the student's learning obstacle of mixed operation of word problem. The purpose of the research is to explore student's learning obstacle in order to plan didactic design of mathematics learning, especially in word problem matter that can be implemented in third grade students elementary school. The approach used in this research is the qualitative approach through the method of Didactical Design Research (DDR). Technique of collecting data uses documentation, interview, test and observation. The data was analyzed qualitatively for knowing student's learning obstacle. The focus of the analysis is based on the theory of didactic situation, and the result of this analysis are used for the development of a didactic design hypothetic. The researcher makes pedagogic didactic anticipation based on identified learning obstacle. The didactic design was implemented in SDN 154 Purwodadi Tanjung Jabung Barat. The result of research showed that student's ontogenical obstacle, didactical obstacle and epistimological obstacle in learning mixed operation of word problem. Based on the above findings, an expected alternative didactical design was composed to minimaze the obstacle that has been identified. From the research it can be concluded that by using this didactic design is one of the alternatives in learning the mixed operation of word problem in elementary school of class III found that learning obstacle can be reduced.
\end{abstract}

Keyword: Didactic design, word problem, mixed operation, learning obstacle.

Abstrak: Penelitian ini dilatarbelakangi oleh munculnya hambatan belajar (learning obstacle) siswa tentang soal cerita operasi hitung campuran. Tujuan penelitian ini adalah mengeksplorasi learning obstacle untuk merancang desain didaktis pembelajaran matematika soal cerita operasi hitung campuran yang dapat diterapkan di kelas III Sekolah Dasar. Pendekatan yang digunakan dalam penelitian ini adalah pendekatan kualitatif melalui metode DDR (Didactical Design Research). Pengumpulan data dilakukan dengan menggunakan teknik dokumentasi, wawancara, tes dan obervasi. Data dianalisis secara kualitatif untuk menemukan learning obstacle. Fokus analisis berdasarkan teori situasi didaktis, dan hasil analisis ini digunakan untuk pengembangan desain didaktis hipotetik. Peneliti menyusun antisipasi didaktis pedagogis berdasarkan learning obstacle yang telah teridentifikasi. Desain didaktis yang telah dirancang tersebut diujicobakan di SDN 154 Purwodadi Tanjung Jabung Barat. Hasil penelitian menunjukkan siswa mengalami ontogenical obstacle, didactical obstacle dan epistimological obstacle pada pembelajaran soal cerita operasi hitung campuran. Berdasarkan temuan diatas, disusunlah suatu desain didaktis alternatif yang diharapkan mampu mengatasi learning obstacle yang telah teridentifikasi. Dari hasil penelitian dapat disimpulkan bahwa penggunaan desain didaktis ini merupakan salah satu alternatif dalam pembelajaran soal cerita operasi hitung campuran di SD kelas III, sehingga learning obstacle siswa dapat dikurangi.

Kata Kunci: Desain didaktis, soal cerita, operasi hitung campuran, learning obstacle

\footnotetext{
${ }^{1}$ Mahasiswa Program Studi Pendidikan Dasar S2 Sekolah Pascasarjana UPI Bandung, Email: sahidagusnurhamid@yahoo.com

${ }^{2}$ Dosen SPs UPI Bandung
} 


\section{PENDAHULUAN}

Matematika merupakan salah satu mata pelajaran yang mempersiapkan dan mengembangkan kemampuan siswa dalam berfikir logis, luwes dan tepat untuk menyelesaikan sebuah masalah yang terjadi dalam kehidupan sehari-hari. Namun sayangnya, banyak siswa yang kesulitan menerjemahkan matematika untuk menyelesaikan persoalan. Matematika dipandang sebagai pelajaran yang terpisah dari permasalahan nyata. Hasil penelitian White (2010) melaporkan bahwa sekitar 70 $\%$ dari kesalahan siswa pada usia 7 tahun adalah pada soal matematika yang khusus berada pada tingkat pemahaman. menghadapi dua persoalan yang harus diselesaikan, yaitu memahami makna soal sekaligus menemukan penyelesaian untuk menjawab soal tersebut. Soal cerita merupalkan soal yang sulit dan kompleks bagi siswa usia sekolah dasar (Daroczy, dkk. 2015).

Soal cerita menjadi permasalahan yang sulit untuk diselesaikan dan menjadi momok bagi sebagian besar siswa, terutama siswa yang mengalami kesulitan membaca pemahaman. Hasil studi pendahuluan menemukan banyak siswa yang mengalami kesalahan dalam menyelesaikan soal cerita. salah satu jawaban siswa dapat ditampilkan sebagai berikut:

Dari jawaban di atas, terlihat bahwa kesulitan

6. Abdul memiliki 20 bungkus permen, Annis memiliki 15 bungkus permen. mereka menggabungkan permen tersebut dan memberikannya ke 5 temannya, setiap satu temannya mendapatkan berapa permen? 21
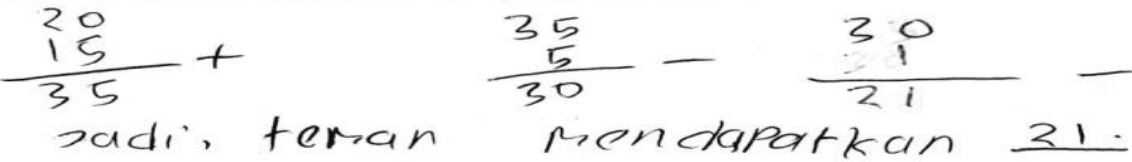

Gambar 1. Respon siswa atas soal cerita uji pendahuluan.

Harapan ini juga belum tercapai oleh sebagian besar anak-anak di Indonesia yang masih memiliki tingkat pemahaman rendah terhadap persoalan matematika. Rendahnya skor yang diperoleh siswa Indonesia disebabkan oleh kurangnya kemampuan menyelesaikan persoalan yang menyangkut pemecahan masalah dan berpikir tingkat tinggi. Persoalan lain yang menjadi tantangan bagi para pendidik di Indonesia adalah rendahnya kemampuan pemahaman siswa dari suatu bacaan. Terdapat permasalahan pada pemahaman membaca siswa SD di Indonesia. Hal yang terjadi kemudian adalah para siswa yang mengalami persoalan pemahaman membaca juga akan bermasalah dalam mencapai prestasi dari pelajaran-pelajarannya, salah satunya matematika, termasuk dalam penyelesaian soal cerita matematika. Kesulitan ini timbul dikarenakan siswa yang dialami siswa dalam menyelesaikan soal cerita adalah kecenderungan siswa untuk melakukan penyelesaian dengan menghitung angka-angka yang tertera dalam soal, tanpa memahami isi soal dengan baik dan teliti. hal ini menyebabkan jawaban yang ditunjukkan siswa keliru dan tidak logis. Hal ini perlu diidentifikasi oleh pendidik untuk menemukan kesulitan yang menjadi penyebab kesalahan menjawab yang dilakukan siswa. Setelah identifikasi kesulitan selanjutnya guru dapat merancang desain pembelajaran untuk meminimalisir kesulitan yang dialami siswa tersebut. Kesulitan-kesulitan yang muncul pada proses pembelajaran baik yang dialami guru maupun oleh siswa yang muncul pada proses pembelajaran disebut dengan hambatan belajar (learning obstacle). Oleh karena itu, dalam tullisan ini, penulis mencoba merancang desain didaktis soal cerita untuk 
meminimalisir learning obstacle siswa pada pembelajaran soal cerita. Dalam penelitian ini penulis memilih materi operasi hitung campuran.

\section{TINJUAN PUSTAKA}

Guru merupakan salah satu aktor penyebab keberhasilan pembelajaran, pengetahuan yang dimiliki siswa di sekolah tidak bisa lepas dari peran guru dalam menyampaikan materi ajar di dalam kelas dan situasi belajar yang dimunculkan. Brousseau (2002) dengan teori didaktisnya mengemukakan bahwa kegiatan pembelajaran yang dilakukan oleh guru dapat memunculkan situasi yang dapat menjadi awal terbentuknya proses pembelajaran. Pembelajaran yang terjadi tidak bisa terlepas dari tiga aspek yang saling berkaitan, yang saling menguatkan, dan saling ketergantungan. Ketiga aspek tersebut menurut Suryadi (2010) adalah guru, siswa, dan materi pembelajaran.

Menurut Suryadi (2013), hubungan didaktis dan pedagogis tidak dapat dipandang secara parsial, tetapi perlu dipahami secara utuh karena dalam kenyataannya kedua hubungan tersebut dapat terjadi secara bersamaan. Dengan demikian pada saat guru merancang sebuah situasi didaktis, maka sekaligus memikirkan prediksi respon siswa atas situasi tersebut beserta antisipasinya sehingga tercipta situasi didaktis baru. dalam hal ini Suryadi menggambarkan dalam bentuk segitiga Didaktis yang dimodifikasi dari segitiga didaktis Kansanen.

Peran guru paling utama dalam konteks segitiga didaktis ini adalah menciptakan suatu situasi didaktis (didactical situation) sehingga terjadi proses belajar dalam diri siswa (learning situation). Ini berarti bahwa seorang guru selain perlu menguasai materi ajar, juga perlu memiliki pengetahuan lain yang terkait dengan siswa serta mampu menciptakan situasi didaktis yang dapat mendorong proses belajar secara optimal.

Hambatan belajar tidak hanya efek dari ketidakmampuan belajar, ketidak pastian, dan kesempatan, tetapi efek dari pengetahuan sebelumnya yang tidak lagi relevan dalam menyelesaikan masalah yang dihadapi saat ini (Brosseau, 2002). Penyebab hambatan belajar menurut Brosseau ada tiga faktor: yaitu hambatan ontogeni (hambatan yang berkaitan dengan mental belajar), hambatan didaktis ( hambatan yang muncul dari pilihan pengajaran yang dilakukan guru), dan hambatan epistimologis (keterbatasan konteks yang dimiliki siswa). Hambatanhambatan tersebut butuh identifikasi dari guru untuk mendesain pembelajaran yang sesuai dan meningkakan kemampuan peserta didik.

Hambatan yang dibahas dalam penelitian ini adalah hambatan belajar siswa dalam menyeleaikan soal cerita. Raharjo,dkk. (2009) mendefinisikan soal cerita sebagai

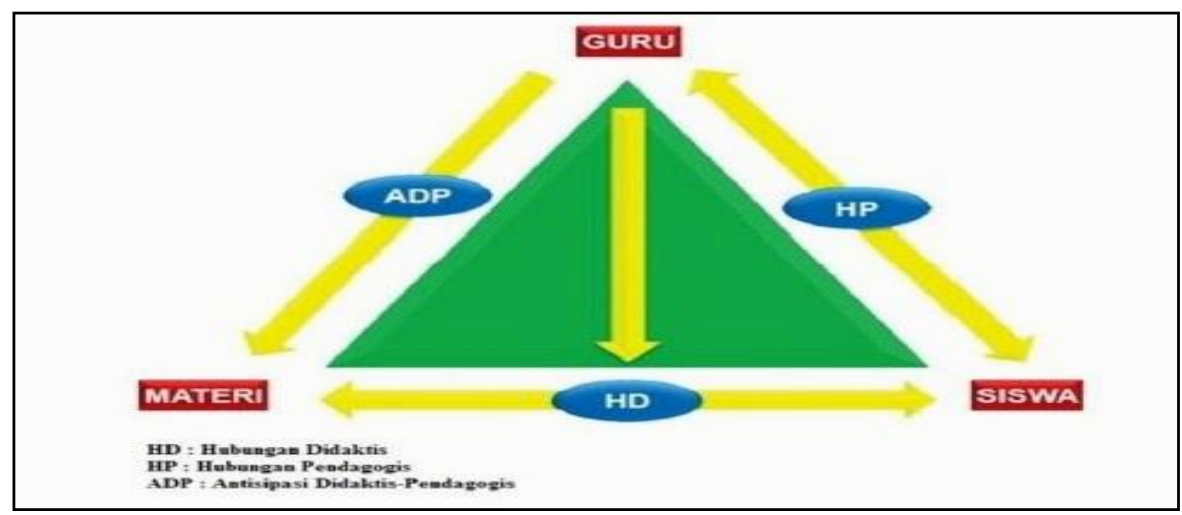

Gambar 2. Segitiga Didaktis yang Dimodifikasi (Suryadi 2013) 
"permasalahan matematika yang berkaitan dengan kehidupan nyata dituangkan melalui soal-soal berbentuk cerita (verbal) sehingga soal cerita adalah soal yang disajikan dalam bentuk cerita yang pendek". Soal cerita mencakup dua komponen utama yaitu kemampuan membaca dan kemampuan menghitung, kemampuan ini harus diseimbangkan (Kilpatrick, 2001) sebagai bekal menghadapi tantangan di masa yang akan datang.

Soal cerita penting dan perlu diajarkan. Soal cerita tidak hanya memiliki potensi memotivasi siswa, mengembangkan konsep-konsep baru dan keterampilan bermakna, tetapi juga mengembangkan keterampilan untuk menerapkan matematika secara efektif dalam kehidupan sehari-hari (Verschaffel, Greer, dan De Corte, 2000), menumbuhkan komunikasi siswa (Kaselin, Sukestiyarno, dan Waluya, 2013), menumbuhkan penalaran yang baik dan peningkatan kemampuan menghubungkan permasalahan dengan dunia nyata (Sepeng dan Webb, 2012). Siswa dapat belajar matematika secara prosedur, tetapi tanpa aplikasi dunia nyata, kemampuan matematika serta keterampilan yang dimiliki dan yang diberikan akan mudah dilupakan.

Kesulitan siswa dalam menyelesaikan soal cerita dikarenakan kosakata yang terbatas (Bailey, 2002), kesalahan dalam merepresentasikan jawaban dan pemikiran ( $\mathrm{Ng}$ dan Lee, 2009), fokus pada kata-kata kunci dan nagka-angka (Capstone dan Fetrow, 2009), dan bentuk soal cerita itu sendiri (Schley dan Fujita, 2014). Clements (dalam Karnasih, 2015) mengungkapkan bahwa kesalahan jawaban siswa dikarenakan kemampuan membaca dan pemahaman yang rendah, kesalahan transformasi dan kecerobohan, lebih lanjut Clements berpendapat pemahaman masalah soal cerita dapat ditingkatkan dengan memperbanyak porsi berbahasa pada pembelajaran matematika.
Penyelesaian permasalahan yang berkaitan dengan soal cerita dapat dilakukan menggunakan langkah-langkah pemecahan masalah Polya (1945) yaitu memahami masalah, merencanakan strategi yang akan digunakan, menyelesaikan masalah menggunakan strategi yang dipilih, dan memeriksa kembali. Abdurrahman (1999) menyatakan bahwa siswa yang tidak melakukan pengecekan kembali akan rentan melakukan kesalahan dalam pengerjaannya karena mengerjakan dengan kurang teliti.

\section{METODOLOGI PENELITIAN}

Fokus penelitian ini adalah untuk merumuskan suatu desain didaktis soal cerita operasi hitung campuran berdasarkan pada learning obstacle yang dialami siswa. pendekatan penelitian ini adalah metode kualitatif dengan pendekatan penelitin desain didaktis (Didactical Design Research) atau yang dikenal dengan DDR. Pengembangan dan uji coba desain didaktis dilakukan dalam tiga lesson design. Hasil implementasi desain didaktis dianalisis untuk menemukan kesulitan hasil belajar siswa. Hasil analisis digunakan untuk mengembangkan desain didaktis alternatif soal cerita operasi hitung campuran yang diharapkan dapat mengurangi learning obstacle yang muncul. Penelitian dilakukan di SDN 154 Purwodadi kabupaten tanjung Jabung barat dengan subjek penelitian kelas III. Teknik pengumpulan data yang digunakan dalam penelitian ini adalah melalui instrumen tes berupa soal, analisis bahan ajar, observasi partisipatif, dan wawancara. Teknik pengumpulan data yang digunakan dalam penelitian ini adalah triangulasi. Triangulasi diartikan sebagai teknik pengumpulan data yang bersifat menggabungkan dari berbagai teknik pengumpulan data dan sumber data yang telah ada (Sugiyono, 2012, hlm.330). Analisis data dilakukan untuk memperoleh variasi dan pola kesalahan siswa dalam memahami konsep soal cerita operasi hitung campuran. pada penelitian ini digunakan 
kriteria derajat kepercayaan (credibility) untuk menetapkan keabsahan data. Adapun teknik pemeriksaan yang digunakan adalah ketekunan pengamatan, triangulasi, diskusi sejawat, dan kecukupan referensi (Moleong, 2011, hlm. 327).

\section{HASIL PENELITIAN DAN PEMBAHASAN}

Hasil penelitian disajikan dalam beberapa bagian, yaitu learning obstacle soal cerita operasi hitung campuran, desain didaktis hipotetik, analisis implementasi desain didaktis hipotetik dan desain didaktis alternatif.

\section{Learning Obstacle}

Berdasarkan hasil uji pemberian soal studi pendahuluan, ditemukan beberapa kesalahan-kesalahan yang dilakukan siswa dalam menyelesaikan soal cerita operasi hitung campuran. kesalahan-kesalahan tersebut dapat dipaparkan sebagai berikut: kesalahan dalam melakukan operasi hitung, kesalahan dalam menentukan operasi hitung, kesalahan dalam merepresentasikan jawaban, kesalahan yang disebabkan belum paham isi bacaan secara keseluruhan (kelemahan dalam membaca pemahaman), dan penggunaan representasi yang sulit dipahami. Dari hasil jawaban yang ditunjukkan pada pembahasan di atas tampak jelas bahwa terdapat ketiga jenis learning obstacle yang terjadi dalam pemberian soal studi pendahuluan. Ketiga learning obstacle tersebut adalah ontogenical obstacle, didactical obstacle dan epistimological obstacle.

Selain pemberian soal untuk mengidentifikasi learning obstacle, penulis juga menganalisis soal cerita yang terdapat dalam buku ajar. hasil analisis ditemukan beberapa soal cerita yang dapat menimbulkan kesulitan sisa menyelesaikan persoalan, seperti terlihat dalam gambar berikut ini:

Soal cerita di atas membutuhkan pemahaman tingkat tinggi, menuntut operasi hitung yang banyak dan menimbulkan kesulitan bagi siswa. selanjutnya dari wawancara yang dilakukan dengan guru kelas III ditemukan informasi bahwa siswa masih berkesulitan menyelesaikan permasalahan soal cerita, penyebabnya adalah kesulitan membaca. Siswa juga melakukan aktivitas menebak langkah penyelesaian, seperti hanya menjumlah, atau mengurang angka-angka yang terdapat dalam soal cerita.

\section{Desain Didaktis Hipotetik}

Setelah melakukan serangkaian studi pendahuluan dan mengidentifikasi learning obstacle yang muncul, peneliti merumusakan suatu desain didaktis hipotetik untuk diimplementasikan kepada siswa kelas III Sekolah Dasar. Desain yang dirancang memuat beberapa situasi didaktis beserta prediksi respon dan antisipasi didaktis yang diberikan berdasarkan prediksi respon tersebut. Teori belajar yang mendukung pengembangan desain didaktis ini antara lain adalah teori belajar Jean Piaget, Bruner, dan Vygotsky, serta langkah-langkah Polya dalam penyelesaian masalah. Adapun desain didaktis hipotetik yang diimplenentasikan terdiri dari 3 desain pembelajaran (lesson design) dengan masing-masing lesson design terdiri dari beberapa situasi didaktis.

\section{Lesson Design Pertama Situasi satu}

Guru bercerita mengenai kambing yang matidan beberapa kambing yang melahirkan, untuk memunculkan respon

9. Mita membeli 6 bungkus bahan minuman. Setiap bngkus dapat dibuat menjadi 6 gelas. Mita menyajikan 2 gelas untuk setiap orang temannya. Berapa gelas minuman yang tersisa jika teman yang datang ada 16 orang?

Gambar 3. Soal cerita pada buku ajar 
siswa mengenai konsep penjmlahan dan pengurangan dalam soal cerita.

Situasi dua: Siswa memerankan soal cerita yang dibacakan oleh guru, dalam pemeranan, dipilih cerita yang memungkinkan adanya pengunaan benda konkrit untuk dimanipulasi siswa, dalam hal ini cerita pemberian permen yang diperanan oleh siswa.

Situasi tiga: Siswa diminta membaca sebuah soal cerita yang dituliskan pada selembar kertas. kegiatan selanjutnya guru meminta siswa yang lain embaca soal cerita yang sama namun disajikan dalam bentuk potonganpotongan kertas karton, yang setiap potongannya memuat satu kalimat saja. kegiatan selanjutnya paa situasi ini memberi batasan pada soal cerita agar memastikan siswa benr-benar berhenti pada tanda pembatas yang ada.

Situasi empat: Pada situasi ini siswa mengerjakan soalcerita secara berkelompok. Kegiatan berkelompok memungkinkan siswa dapat bekerja sama dan memahami persoalan, mencari solusi, dan melaksanakan solusi tersebut secara bersama-sama.

Situasi lima: Pada situasi ini siswa diberi soal cerita penjumlahan, pengurangan dan soal cerita hitung campuran penjumlahan dan pengurangan secara individu.

\section{Lesson Design Kedua}

Situasi satu: Guru meletakkan 4 buku tulis dan menempelkan harga Rp. 1500/buku. Guru meminta siswa menemukan harga 4 buku, 5 buku, dan sebagainya. Selanjutnya meletakkan 5 buku tulis, dan menempelkan harga untuk keseluruhan buku tersebut Rp. 15.000. Siswa diminta menemukan harga jika hanya membeli 1 buku dan jika hanya membeli 2 buku. Guru meminta siswa menuliskan cara menghitung masalah di atas pada papan tulis. Dengan mengadakan tanya jawab dengan siswa, diharapkan siswa menemukan bahwa soal tersebut merupakan contoh soal cerita perkalian dan pembagian.

Situasi dua: Kegiatan selanjutnya adalah memberikan beberapa soal cerita perkalian dan pembagian dan membagikan media manipulatif berupa sedotan dan gambaran ke masing-masing kelompok. Selanjutnya siswa mengidentifikasi perbedaan jenis soal cerita perkalian dan pembagian secara berkelompok.

Situasi tiga: Pada situasi ini siswa menyelesaikan soal cerita perkalian, pembagian dan soal cerita hitung campuran antara perkalian dan pembagian secara individu.

\section{Lesson Design Ketiga}

Situasi satu: Pada situasi ini materi yangdisampaikan engenai soal cerita hitung campuran. Guru menempelkan soal cerita di papan tulis. berikut soal ceritanya:

Andi memiliki 10 sedotan, Budi memiliki 15 sedotan, lalu ayah memberi 14 sedotan kepada Andi dan Budi untuk dibagi sama banyak. Berapa seluruh sedotan Andi sekarang?

Guru meminta siswa memeragakan cerita di atas, setelah selesai memeragakan dan menemukan hasilnya, guru bersama siswa menuliskan kalimat matematika dari soal tersebut. Kalimatyang ditulis adalah $10+14$ : 2 . Guru meminta siswa membandungkan jawaban yang ditemukan siswa, apakah terjadi perbedaan, selanjutnya meminta siswa menjelaskann jawabannya masing-masing.

Situasi dua: pada situasi ini pembelajaran dilakukan dengan mengadakan kegiatan bermain peran jual beli di koperasi sekolah, kelas didesain sedemikian rupa seakan-akan menjadi sebuah koperasi sekolah yang menjual berbagai keperluan sekolah. Guru merancang pembelajaran soal cerita hitung campuran dalam kegiatan ini. Media yang digunakan adalah kumpulan barang keperluan sekolah yang dibuat dalam bentuk gambar, daftar harga dan uang tiruan sebagai alat pembayaran.

Situasi tiga: Guru membagi siswa dalam kelompok-kelompok, memberi daftar harga barang koperasi sekolah, dan uang-uangan, 
selanjutnya memberikan soal cerita yang berkaitan dengan uang.

Situasi empat: Meminta siswa membuat soal cerita secara mandiri. Pembuatan soal secara mandiri merupakan aplikasi dari materi soal cerita. Kemampuan siswa dalam memahami soal cerita diujikan dengan membuat soal cerita secara mandiri. Guru memberi kebebasan kepada siswa untuk menentukan jenis soal cerita yang dibuat, penjumlahan, pengurangan, perkalian, pembagian ataupun soal cerita hitung campuran.

Situasi lima: Menyelesaikan soal cerita operasi hitung campuran secara individu. Soal cerita yang dibagikan adalah soal cerita operasi hitung campuran. Berbeda dengan soal cerita pada lesson design pertama dan kedu, pada lesson design ketiga, soal cerita yang diberikan adalah soal cerita operasi hitung campuran yang memuat penjumlahan, pengurangan, perkalian atau pembagian.

\section{Analisis Implementasi Desain Didaktis Hipotetik}

Dalam implementasinya kegiatan pembelajaran terlaksana dalam 4 pertemuan. Hal ini dikarenakan lesson design ketiga tidak dapat dilaksanakan dalam satu kegiatan, sehingga peneliti menambahkan pertemuan, situasi empat dan situasi lima dilaksanakan pada pertemuan keempat. Berdasarkan implementasi desain didaktis, ditemukan learning obstacle siswa seperti yang terlihat dalam tabel sebagai berikut:

Tabel 1. Rekapitulasi Learning Obstacle yang ditemukan selama implementasi Desain Didaktis Hipotetik

\begin{tabular}{|c|c|c|}
\hline $\begin{array}{l}\text { Implementasi } \\
\text { Desain }\end{array}$ & Kesulitan yang Teridentifikasi & Learning Obstacle \\
\hline $\begin{array}{l}\text { Pertemuan } \\
\text { Pertama }\end{array}$ & $\begin{array}{l}\text { 1) Kesalahan dalam menentukan jumlah hasil peragaan. } \\
\text { 2) Kesalahan dalam memilih operasi hitung. } \\
\text { 3) Kesalahan dalam melakukan pengurangan meminjam. } \\
\text { 4) Tidak memeriksa jawaban. } \\
\text { 5) Kesulitan membaca dan memaknai isi bacaan }\end{array}$ & $\begin{array}{l}\text { Ontogenical obstacle }(1,5) \\
\text { Didactical obstacle }(3,4) \\
\text { Epistimological obstacle }(1, \\
\text { 2) }\end{array}$ \\
\hline $\begin{array}{l}\text { Pertemuan } \\
\text { Kedua }\end{array}$ & $\begin{array}{l}\text { 1) Kesulitan menentukan jenis soal cerita. } \\
\text { 2) Kesalahan dalam merepresentasikan jawaban } \\
\text { menggunakan media. } \\
\text { 3) Kecenderungan memilih penggunaan penjumlahan } \\
\text { berulang untk menyelesaikan perkalian. } \\
\text { 4) Sudah memeriksa jawaban, tetapi pemeriksaan yang } \\
\text { dilakukan masih keliru. } \\
\text { 5) Kesulitan mengkomunikasikan jawabannya ke dalam } \\
\text { kalimat matematika. } \\
\text { 6) Kesulitan membaca dan memahami isi soal. }\end{array}$ & $\begin{array}{l}\text { Ontogenical obstacle }(1,4, \\
7) \\
\text { Didactical obstacle }(1,3,5) \\
\text { Epistimological obstacle }(3, \\
4,6)\end{array}$ \\
\hline $\begin{array}{l}\text { Pertemuan } \\
\text { Ketiga }\end{array}$ & $\begin{array}{l}\text { 1) Kesalahan dalam melakukan penghitungan, siswa } \\
\text { menghitung } 10+14: 2=12 \\
\text { 2) Kesulitan mengingat konsep operasi hitung campuran. } \\
\text { 3) Kesalahan dalam melakukan perintah dalam soal cerita. } \\
\text { 4) Kesulitan melakukan penghitungan operasi pembagian. }\end{array}$ & $\begin{array}{l}\text { Ontogenical obstacle }(1,2, \\
5) \\
\text { Didactical obstacle } \\
\text { Epistimological obstacle }(1, \\
2,3,4)\end{array}$ \\
\hline $\begin{array}{l}\text { Pertemuan } \\
\text { Keempat }\end{array}$ & $\begin{array}{l}\text { 1) Pembuatan soal cerita yang tidak memuat perintah } \\
\text { pengerjaan/ kalimat tanya. } \\
\text { 2) Tidak memeriksa soal yang dibuat. } \\
\text { 3) Kesalahan dalam membuat soal cerita pengurangan dan } \\
\text { pembagian. } \\
\text { 4) Kesalahan menghitung. } \\
\text { 5) Kesulitan menyelesaikan seluruh perintah dalam soal } \\
\text { cerita. } \\
\text { 6) Kesalahan memilih operasi hitung. } \\
\text { 7) Kesulitan dalam mengkomunikasikan jawaban. }\end{array}$ & $\begin{array}{l}\text { Ontogenical obstacle }(1,4, \\
5,6) \\
\text { Didactical obstacle }(2,3) \\
\text { Epistimological obstacle } \\
(1,4,5,6,7)\end{array}$ \\
\hline
\end{tabular}


Berdasarkan hasil diatas, maka disusunlah desain didaktis alternatif untuk meminimalisir learning obstacle yang muncul, perumusan desain juga didasarkan pada alur belajar siswa selama implementasi. Desain didaktis alternatif disusun dengan tujuan meminimalisir learning obstacle yang muncul selama implementasi. Desain didaktis ini disusun setiap situasi belajar, untuk memudahkan melihat apakah kegiatan yang diimplementasikan perlu direvisi atau dapat dipertahankan.

\section{Desain Didaktis Alternatif Lesson Design Alternatif Pertama}

Situasi belajar satu yang berupa pembacaan soal cerita direvisi. Revisi terjadi pada cerita yang dibacakan, berdasarkan analisis implementasi, soal mengenai kambing kurang menarik siswa, guru mengganti kambing dengan kelinci, agar siswa antusias mendengarkan cerita yang dibacakan, dan lebih siap menerima materi soal cerita. Guru menambahkan beberapa yang akan dikerjakan siswa, penyederhanaan bahasa, menyederhanakan angka-angka, dan pengurangan jumlah soal. Bagi siswa yang berkesulitan membaca, diberikan bantuan dengan membacakan soal kepada siswa.

\section{Lesson Design Alternatif Kedua}

Situasi satu dapat dipertahankan. Agar siswa tidak hanya terfokus pada masalah uang, revisi dari situasi ini adalah menambahkan pemberian soal cerita perkalian dan pembagian yang tidak melibatkan penggunaan uang. Penulisan kalimat matematika diberikan contoh di papan tulis, selanjutnya untuk menguatkan konsep perkalian dan pembagian siswa, guru memberi bimbingan berupa pemberian soal non-cerita perkalian dan pembagian. Situasi dua dapat dipertahankan, kegiatan kelompok yang dilakukan siswa lebih diefektifkan agar terjalin kerjasama kelompok dan tumbuhnya rasa kebersamaan ketika melakukan pemecahan masalah bersama.

Situasi tiga mendapat revisi berupa penambahan kalimat perintah pada soal. berdasarkan analisis implementasi,

\section{Soal sebelumnya}

Siswa kelas III berjumlah 22 orang, setiap satu anak membawa 4 buah buku. Berapa buku yang terkumpul seluruhnya?

\section{Soal revisi}

Siswa kelas III berjumlah 22 orang, setiap satu anak membawa 4 buah buku. Berapa buku yang terkumpul seluruhnya? Temukan jawabanmu dengan menggunakan dua cara yang berbeda.

Gambar 4. Soal yang mengalami perbaikan.

gambar kelinci sebagai media bercerita. Pemeranan pada situasi dua lebih diefektifkan. Cerita yang disajikan dipersiapkan secara detail, dan jelas. Untuk mencegah kesalahan dan ketidaktepatan jumlah permen seperti dalam implementasi, media permen yang digunakan untuk peragaan diantisipasi dengan dihitung terlebih dahulu secara teliti. Pada situasi empat dan lima, revisi berupa pemberian instruksi yang lebih jelas untuk soal-soal ditemukan siswa yang menghitung soal cerita perkalian menggunakan penjumlahan berulang. Untuk memunculkan penggunaan perkalian, perlu penambahan perintah dalam soal. Penambahan tersebut berupa "temukan jawabanmu menggunakan dua cara yang berbeda“. Berikut soal yang mengalami perbaikan.

Dengan pemberian perintah seperti di atas, diharapkan siswa menemukan cara 
bahwa soal tersebut dapat diselesaikan dengan cara lain, seperti perkalian.

\section{Lesson Design Alternatif Ketiga}

Lesson design alternatif ketiga mencakup kegiatan-kegiatan yang dalam implementasi dilakukan pada pertemuan ketiga dan keempat. Dalam desain revisi ini, kegiatan pada dua pertemuan tersebut disajikan dalam pertemuan ketiga. Kegiatan pemeranan diganti dengan menempelkan soal cerita di papan tulis, siswa dibagikan sedotan masing-masing meja sebanyak 40 sedotan untuk dipergunakan dalam menyelesaikan persoalan. Penulisan kalimat matematika tidak ditulis oleh guru, tetapi meminta beberapa siswa menuliskan sendiri di papan tulis. Pembagian sedotan dimaksudkan agar siswa memperoleh keyakinan bahwa jawaban yang mereka tunjukkan benar sehingga siswa menemukan konsep penghitungan operasi hitung campuran. Konsep yang dimaksud adalah jika terdapat operasi penjumlahan dan pembagian, pengerjaan tidak langsung dari sebelah kiri, melainkan dengan mendahulukan operasi pembagian.

Kegiatan jual beli dimodifikasi dengan menyelesaikan soal-soal cerita yang dibagikan berupa soal cerita operasi hitung campuran. Setiap kelompok diberikan satu daftar harga barang-barang di koperasi sekolah, dan uang-uangan yang dibagikan secara merata. Selanjutnya masing-masing kelompok menyampaikan hasil kerjanya di depan kelas untuk didiskusikan. Kegiatan membuat soal cerita secara mandiri dipertahankan. Terdapat penambahan perintah yang meminta siswa membuat soal cerita tertentu, soal cerita yang diminta adalah soal cerita operasi hitung campuran. Berdasarkan analisis implementasi, penyebab kesulitan yang dialami siswa adalah kesulitan dalam mencari permasalahan untuk disajikan dalam bentuk soal cerita, kesulitan membuat kalimat pertanyaan, tidak memeriksa soal sehingga soal cerita yang dibuat tidak memiliki jawaban yang sesuai. Untuk mengantisipasi hambatan tersebut, guru memberi bantuan dengan meminta siswa membuat soal cerita tentang sesuatu yang dekat dengan siswa. Guru juga memberi antisipasi dengan meminta siswa membaca ulang soal yang dibuat, dan memeriksa apakah soal yang dibuat memiliki penyeleaian yang tepat. Guru mengingatkan bahwa dalam pembuatan soal cerita pengurangan dan pembagian, harus bisa memprediksi jawaban, karena berkemungkinan angka yang berfungsi sebagai pengurang lebih kecil dari angka yang dikurangi, demikian juga pada pembagian. Guru memberi contoh kepada untuk mempermudah siswa menerima penjelasan. Situasi yang terakhir, pemberian soal secara individu dilakukan di akhir desain didaktis alternatif ini. kesulitan-kesulitan yang terjadi dalam penyelesaian soal cerita diantisipasi dengan memberi instruksi yang jelas, menyederhanakan soal cerita, membuat soal cerita yang tidak banyak menggunakan operasi hitung, mengingatkan siswa untuk membuat penggambaran dalam meyelesaikan soal, memeriksa jawaban kembali, membimbing siswa untuk mengungkapkan jawabannya, dan memberikan bantuan kepada siswa yang berkesulitan membaca.

\section{KESIMPULAN}

Learning obstacle yang dialami siswa kelas III sekolah dasar pada materi soal cerita operasi hitung campuran adalah sebagai berikut: Ontogenical obstacle, didactical obstacle dan epistiological obstacle. Learning obstacle ditemukan berdasarkan respon selama implementasi maupun respon yang terdapat pada kesalahan-kesalahan siswa dalam menyelesaikan soal cerita yang diberikan. Berdasarkan temuan-temuan tersebut, maka disusunlah desain didaktis alternatif soal cerita operasi hitung campuran kelas III sekolah dasar meliputi: penggunaan strategi pemecahan masalah dan 
pemanfaatan tahap belajar siswa dari tahap enaktif, ikonik, dan simbolik. Pembelajaran soal cerita diberikan dengan menekankan pemahaman isi soal, pemaknaan kata/kalimat pada soal cerita, dan penentuan strategi penghitungan yang dilakukan. Soal cerita yang dirancang disesuaikan dengan kemampuan siswa. Desain ini merupakan desain alternatif yang dirancang berdasarkan learning obstacle yang dialami siswa selama implementasi dilakukan. Desain didaktis alternatif yang ditawarkan memuat dua belas situasi didaktis yang terbagi dalam tiga lesson design. Situasi didaktis yang disusun memperhatikan aspek-aspek yang telah dibahas sebelumnya termasuk didalamnya prediksi respon siswa serta antisipasi didaktis sebagai upaya membantu proses belajar lebih terarah. Desain didaktis alternatif yang dihasilkan senantiasa fleksibel, dapat dirubah dan disesuaikan berdasarkan kondisi di lapangan dan berdasarkan respon yang didapat dari siswa. Serta disesuaikan dengan memperhatikan tahap perkembangan siswa.

\section{DAFTAR PUSTAKA}

Abdurrahman, M. (1999). Pendidikan Bagi Anak Berkesulitan Belajar. Jakarta: Depdikbud \& PT. Rineka Cipta.

Bailey, T. (2002). Taking The Problems Out of Word Problems. Teaching PreK-8, 32 (4), hlm. 60-61.

Brousseau, G. (2002). Theory of Didactical Situations in Mathematics. Dordrecht: Kluwer Academic Publishers.

Capstone, B \& Fetrow, J. (2009). Word Problem in Math. $6^{\text {th }}$ Grade Teacher. [Online]. http://files.eric.ed.gov/fulltext/ED5062 37.pdf.

Daroczy, G. dkk. (2015). Word Problems: A Review of Linguistic and Numerical Factors Contributing to Their Difficulty. Fontier in Psychology, 6 (348), hlm. 1-13.
DOI: $\quad \underline{10.3389 / \text { fpsyg.2015.00348. }}$ PMCID: PMC4381502

Karnasih, I. (2015). Analisis kesalahan Newman pada Soal Cerita Matematis (Newman's Error Analysis in Mathematical Word Problems). Jurnal PARADIKMA, 8 (1), hlm. 37-51.

Kaselin, Sukestiyarno, \& Waluya (2013). Kemampuan Komunikasi Matematis pada Pembelajaran Matematika dengan Strategi REACT Berbasis Etnomatematika. Unnes Journal of Mathematics Education Research. 2 (2), hlm. 121-127.

Kilpatrick, Swaford, J., \& Indell, B. (2010). Adding It Up: Helping Children Learn Mathematics. Washington DC: National Academy Press.

Moleong, L.J. (2011). Metodologi Penelitian Kualitatif. Bandung: Remaja Rosdakarya.

Ng S. F., \& Lee, K. (2005) How Primary Five Pupils Use the Model Method to Solve Word Problems. The Mathematics Educator, 9, (1), hlm. 6083.

Polya (1945) How to Solve It. (2nd Edition). Princeton, NJ: Princeton University Press Raharjo, M., Ekawati, \& Rudianto. (2009). Modul Matematika SD Program BERMUTU : Pembelajaran soal cerita di SD. Jakarta: Depdiknas.

Schley, D. R. \& Fujita, K. (2014). Seeing the Math in the Story: On How Abstraction Promotes Performance on Mathematical Word Problems. Social Psychological and Personality Science, 5(8), hlm. 953-961.

Sepeng, P. \& Webb, P. (2012). Exploring Mathematical Discussion in Word Problem Solving. Pythagoras, 33 
(1),hlm. $\quad 1-8 . \quad$ DOI: 10.4102/pythagoras.v33i1.60.

Sugiyono (2012). Metode Penelitian Pendidikan. Pendekatan kuantitatif, kualitatif \& $R \& D$. Bandung: Alfabeta.

Suharyanto, \& Jacob, C. (2009). Matematika 3 (BSE). Jakarta: Pusat Perbukuan Depdiknas.

Suryadi, D. (2010). Menciptakan Proses Belajar Aktif: Kajian dari Sudut Pandang Teori Belajar dan Teori Didaktik. Bandung: Tidak diterbitkan.

Suryadi, D. (2013) Didactical Design Research (DDR) to Improve the Teaching of Mathematics. Ar East Journal Mathematical Education. 10(1), hlm. 91-107.

Verschaffel, L., Greer, B. \& De Corte, E. (2000). Making Sense of Word Problems, Lisse, The Netherlands, Swets and Zeitlinger Publishers. ISBN 9026516282.

White, A.L (2010). Numeracy, Literacy and Newman's Error Analysis. Journal of Science and Mathematics Education in Southeast Asia, 33 (2) hlm. 129 - 148. 